\title{
GAMBARAN MOTIVASI DAN PARTISIPASI KELUARGA DALAM PERAWATAN MANDIRI PASIEN GAGAL JANTUNG
}

\author{
Adella Indri Afitasari ${ }^{1}$, Beti Kristinawati ${ }^{1}$ \\ ${ }^{1}$ Keperawatan Medikal Bedah, Universitas Muhammadiyah Surakarta, Indonesia \\ Corresponding author: j210160102@student.ums.ac.id
}

\begin{abstract}
The inability of the heart to pump blood adequately accompanied by dyspnea causes people with heart failure to have physical limitations. These symptoms result in the patient being unable to perform self-care optimally, so they need help from others, especially family. This study aims to identify the description of motivation and family participation in the self-care of heart failure patients. The research design used was descriptive quantitative research with 152 respondents who were drawn by purposive sampling technique. The results showed 62.5\% women, and aged between 40-59 years. Forms of family motivation are family care about the patient's illness, family acceptance of the patient's condition, and family assistance to a health service center. Family participation was divided into three, with the highest score being self-care management who contacted the doctor or nurse, and advised the family to take medication when symptoms appeared. Participate in self-care with an assessment of readiness to work, and follow given medication instructions. Then the maintenance of self-care, namely leaving the family to exercise control with a doctor or nurse, and treatment of patients so they don't drink, forget to drink using a medicine box.
\end{abstract}

Keywords: Heart failure, motivation, family participation

\section{PENDAHULUAN}

Gagal jantung atau heart failure adalah sindrom klinis kompleks yang ditandai dengan ketidakmampuan jantung dalam memompa darah secara adekuat (Bachrudin \& Najib, 2016). Prevalensi gagal jantung di Amerika sekitar 6.2 juta orang tercatat antara 2013-2016 (AHA, 2019). Data di Indonesia menunjukkan bahwa prevalensi penyakit jantung terbanyak adalah Provinsi Kalimantan Utara yaitu 2.2\% (Kementrian Kesehatan Indonesia, 2018). Angka kematian akibat gagal jantung di rumah sakit mencapai $12 \%$ serta tingkat rawat inap kembali atau readmission sekitar 29\% (Prihatiningsih \& Sudyasih, 2018). Prevalensi kejadian rawat inap ulang menurun ketika penderita gagal jantung mampu melakukan perawatan mandiri di rumah (Agustina, dkk., 2017).

Hasil penelitian Riegel, dkk (2009) menunjukkan bahwa pasien dengan gagal jantung baik di negara maju maupun berkembang memiliki perilaku perawatan diri yang rendah. Untuk meningkatkan kualitas perawatan diri pasien, peningkatan perbaikan gejala, morbiditas, prognosis dan keberhasilan dalam pengobatan gagal jantung diperlukan manajemen keperawatan mandiri yang efektif (PERKI, 2015). Upaya untuk meningkatkan perawatan mandiri pada pasien gagal jantung yang penting untuk 
Jurnal Ilmu Keperawatan Medikal Bedah Vol. 3 (2), Bulan November Tahun 2020 , Hal. 32-41 ISSN 2338-2058 (print), ISSN 2621-2986 (online)

dilakukan seperti diet, kepatuhan pengobatan, dan pencegahan readmission (Andersen \& Strom, 2016).

Gagal jantung dengan kelas fungsional III dan IV sudah mengalami banyak keterbatasan fisik sehingga pasien tidak mampu untuk melakukan perawatan mandiri dan memerlukan bantuan orang sekitar dan keluarga. Dukungan sosial terutama dukungan keluarga dan orang-orang sekitar pasien sangat penting untuk meningkatkan kepercayaan diri pasien dalam melakukan perawatan mandiri. Proses penyembuhan akan semakin efektif jika terdapat kerjasama dan partisipasi penuh dari keluarga (Fikriana, 2018). Peran aktif serta motivasi dari anggota keluarga dapat memberikan energi positif bagi seorang pasien dalam menghadapi penyakitnya. Pasien yang memiliki motivasi yang tinggi akan berjuang melawan penyakitnya walaupun harapan untuk pemulihan tipis (Fauzi \& Yuniarti, 2017). Wawancara motivasi secara efektif dapat meningkatkan perawatan diri pasien gagal jantung dibandingkan pendidikan kesehatan tradisional, wawancara motivasi memiliki efek yang lebih signifikan (Chen, dkk., 2018).

Berdasarkan hasil studi pendahuluan yang dilakukan pada 8 Oktober 2019 di RSUD Dr. Moewardi didapatkan bahwa angka kejadian rawat jalan pasien gagal jantung pada periode Juli-September 2019 terdapat 212 pasien menjalani rawat jalan dan sebanyak 52 pasien menjalani rawat inap. Hasil studi literartur juga didapatkan bahwa motivasi dan partisipasi keluarga dalam perawatan mandiri pasien gagal jantung masih rendah. Dari 8 keluarga pasien didapatkan bahwa 6 orang (75\%) masih rendah terhadap motivasi diit rendah garam terutama saat makan diluar, dan hanya 3 orang (37.5\%) memiliki partisipasi yang cukup baik dalam membantu mengingat obat. Dampak dari motivasi keluarga dapat meningkatkan kualitas hidup sebesar $95 \%$ pada pasien dibandinkan dengan tidak mendapatkan motivasi keluarga (Barbara, 2017). Tujuan dari penelitian ini untuk mengetahui gambaran motivasi dan partisipasi keluarga dalam perawatan mandiri pasien gagal jantung.

\section{METODE}

Penelitian ini merupakan penelitian deskriptif kuantitatif dengan metode survey. Sampel yang digunakan dalam penelitian ini adalah keluarga pasien dengan gagal jantung berjumlah 152 responden yang melakukan rawat jalan di poliklinik jantung RSUD Dr.Moewardi Surakarta, dan yang tinggal satu rumah dengan pasien minimal 6 bulan. Teknik sampling yang digunakan dalam penelitian ini adalah purposive sampling. Rancangan penelitian ini telah dinyatakan layak etik oleh Komisi Etik Penelitian Kesehatan RSUD Dr.Moewardi dengan nomor 1.254/XI/HREC/2019.

Instrumen penelitian yang digunakan adalah kuesioner motivasi (Fauzi \& Yuniarti, 2017) yang telah dimodifikasi dan kuesioner Caregiver Contribution Self Care of Heart Failure Index (CC-SCHFI) versi 1 (Vellone, 2013) yang telah diterjemahkan dalam Bahasa Indonesia. Kuesioner motivasi terdiri dari 8 pertanyaan dan kuesioner CC-SCHFI terdiri dari 3 dimensi penilaian terhadap partisipasi keluarga dalam perawatan mandiri pasien gagal jantung dengan jumlah total 22 pertanyaan.

Analisis yang digunakan adalah analisis univariat yang digunakan untuk menyajikan distribusi frekuensi serta persentase terhadap variabel motivasi dan partisipasi keluarga beserta faktor demografi responden.

Afitasari, A.I., Krisnawati, B._Gambaran Motivasi dan Partisipasi Keluarga dalam... 
Jurnal Ilmu Keperawatan Medikal Bedah Vol. 3 (2), Bulan November Tahun 2020 , Hal. 32-41 ISSN 2338-2058 (print), ISSN 2621-2986 (online)

\section{HASIL}

Data hasil penelitian yang diperoleh kemudian dianalisis menggunakan analisis univariat, yang meliputi data karakteristik demografi responden, motivasi yang diberikan oleh keluarga, dan perilaku keluarga dalam perawatan mandiri pasien gagal jantung.

Tabel 1

Karakteristik Demografi Reponden (n=152)

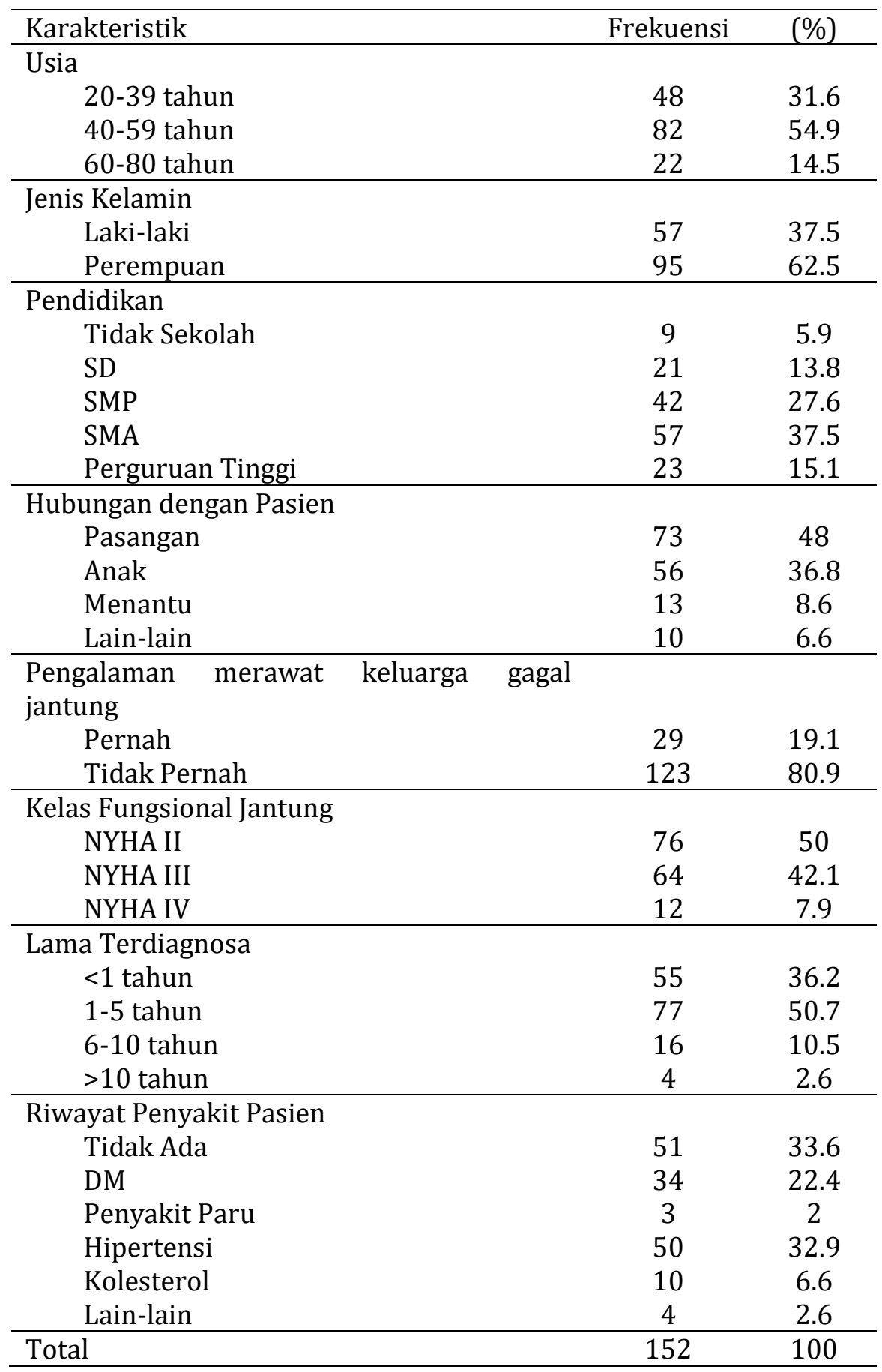

Afitasari, A.I., Krisnawati, B._Gambaran Motivasi dan Partisipasi Keluarga dalam... 
Jurnal Ilmu Keperawatan Medikal Bedah Vol. 3 (2), Bulan November Tahun 2020 , Hal. 32-41 ISSN 2338-2058 (print), ISSN 2621-2986 (online)

Berdasarkan jenis kelamin responden mayoritas adalah perempuan $(62.5 \%)$ dengan usia rata-rata pada rentang 40-59 tahun. Responden mayoritas berpendidikan SMA sederajat. Sebanyak 36.8\% responden merupakan pasangan dan $80.9 \%$ tidak memiliki pengalaman merawat pasien dengan sakit jantung sebelumnya.

Tabel 2

Deskripsi motivasi keluarga dalam perawatan mandiri pasien

\begin{tabular}{llcc}
\hline No. & Bentuk Motivasi & Mean & Std. Deviasi \\
\hline 1. & Menyediakan sarana berupa dana untuk pengobatan pasien. & 2.81 & 0.982 \\
2. & Mendampingi saat berkunjung ke pusat layanan kesehatan & 3.12 & 0.898 \\
3. & Peduli mengenai penyakit yang dialami pasien & 3.33 & 0.607 \\
4. & Menerima keadaan pasien & 3.28 & 0.663 \\
5. & Memberikan saran untuk mematuhi anjuran dokter & 2.73 & 0.772 \\
6. & Memberikan semangat dan dukungan ketika terjadi keluhan & 2.70 & 0.935 \\
7. & Membantu merencanakan pengobatan & 2.18 & 0.986 \\
8. & Mencari informasi mengenai penyakit gagal jantung & 1.61 & 0.807 \\
\hline & Total & 2.72 & 0.714 \\
\hline
\end{tabular}

Tabel 2 menggambarkan deskripsi motivasi keluarga dan didapatkan bahwa bentuk motivasi yang paling banyak diberikan oleh keluarga adalah peduli mengenai penyakit yang dialami pasien, kemudian pada motivasi keluarga untuk menerima keadaan pasien, selanjutnya adalah motivasi untuk mendampingi saat berkunjung ke pusat layanan kesehatan. Bentuk partisipasi yang masih perlu ditingkatkan adalah motivasi keluarga dalam mencari informasi mengenai penyakit gagal jantung selain informasi dari dokter ataupun petugas kesehatan ketika kontrol.

Tabel 3

Deskripsi partisipasi keluarga dalam pemeliharaan diri pasien (Caregiver Contribution to Self-Care Maintenance)

\begin{tabular}{|c|c|c|c|}
\hline No & Bentuk Partisipasi & Mean & Std. Deviasi \\
\hline 1. & Menganjurkan keluarga untuk memeriksa berat badan & 2.01 & 0.728 \\
\hline 2. & $\begin{array}{l}\text { Menganjurkan keluarga untuk memeriksa bengkak pergelangan } \\
\text { kaki }\end{array}$ & 1.49 & 0.671 \\
\hline 3. & $\begin{array}{l}\text { Menganjurkan keluarga untuk menghindari sakit (contoh, } \\
\text { konsumsi vitamin untuk mencegah flu, menghindari orang sakit) }\end{array}$ & 2.18 & 0.720 \\
\hline 4. & Menganjurkan keluarga untuk melakukan beberapa aktifitas fisik & 1.89 & 0.696 \\
\hline 5. & $\begin{array}{l}\text { Menganjurkan keluarga untuk melakukan kontrol dengan dokter } \\
\text { atau perawat }\end{array}$ & 3.05 & 0.740 \\
\hline 6. & Menganjurkan keluarga untuk makan makanan rendah garam & 2.41 & 0.800 \\
\hline 7. & $\begin{array}{l}\text { Menganjurkan keluarga untuk melakukan olah raga selama } 30 \\
\text { menit }\end{array}$ & 1.76 & 0.690 \\
\hline 8. & Menganjurkan keluarga untuk tidak lupa minum obat & 2.69 & 0.765 \\
\hline 9. & $\begin{array}{l}\text { Meminta makanan rendah garam saat makan di luar atau saat } \\
\text { bertamu }\end{array}$ & 1.43 & 0.678 \\
\hline 10. & $\begin{array}{l}\text { Menganjurkan keluarga untuk menggunakan alat (kotak obat atau } \\
\text { pengingat) untuk membantu mengingat obat }\end{array}$ & 1.44 & 0.668 \\
\hline & Total & 2.035 & 0.716 \\
\hline
\end{tabular}

Afitasari, A.I., Krisnawati, B._Gambaran Motivasi dan Partisipasi Keluarga dalam... 
Jurnal Ilmu Keperawatan Medikal Bedah Vol. 3 (2), Bulan November Tahun 2020 , Hal. 32-41 ISSN 2338-2058 (print), ISSN 2621-2986 (online)

Tabel 4

Deskripsi partisipasi keluarga dalam pengelolaan diri pasien (Caregiver Contribution to Self-Care Management)

\begin{tabular}{llcc}
\hline No & \multicolumn{1}{c}{ Bentuk Partisipasi } & Mean & SD \\
\hline 1. & Kecepatan dalam menyadari gejala gagal jantung & 2.39 & 0.799 \\
2. & $\begin{array}{l}\text { Menyarankan keluarga untuk membatasi garam } \\
\text { dalam makanan yang dikonsumsi }\end{array}$ & 2.40 & 0.612 \\
3. $\quad \begin{array}{l}\text { Menyarankan keluarga untuk mengurangi } \\
\text { konsumsi cairan }\end{array}$ & 2.45 & 0.726 \\
4. $\quad \begin{array}{l}\text { Menyarankan keluarga untuk mengonsumsi } \\
\text { furosemid tambahan }\end{array}$ & 2.90 & 0.717 \\
5. $\quad \begin{array}{l}\text { Menyarankan keluarga untuk menghubungi } \\
\text { dokter atau perawat untuk panduan }\end{array}$ & 3.39 & 0.600 \\
6. $\quad \begin{array}{l}\text { Seberapa yakinkah Anda bahwa cara tersebut } \\
\text { menolong atau tidak? }\end{array}$ & 2.53 & 1.010 \\
\hline \multicolumn{2}{c}{ Total } \\
\hline
\end{tabular}

Tabel 5

Deskripsi partisipasi keluarga dalam kepercayaan diri pasien (Caregiver Contribution to Self-Care Confidence)

\begin{tabular}{llcc}
\hline No & Bentuk Partisipasi & Mean & $\begin{array}{c}\text { Std. } \\
\text { Deviasi }\end{array}$ \\
\hline 1. & $\begin{array}{l}\text { Keyakinan untuk membuat keluarga Anda terhindar } \\
\text { dari gejala-gejala gagal jantung }\end{array}$ & 2.57 & 0.627 \\
2. & $\begin{array}{l}\text { Mengikuti petunjuk pengobatan yang telah diberikan } \\
\text { 3. }\end{array}$ & 2.67 & 0.654 \\
& $\begin{array}{l}\text { Mengevaluasi pentingnya gejala gagal jantung yang } \\
\text { ada pada keluarga }\end{array}$ & 2.39 & 0.702 \\
4. & $\begin{array}{l}\text { Mengenali perubahan pada keluarga ketika } \\
\text { perubahan terjadi }\end{array}$ & 2.47 & 0.671 \\
5. & $\begin{array}{l}\text { Melakukan sesuatu yang mengurangi gejala-gejala } \\
\text { gagal jantung }\end{array}$ & 2.60 & 0.607 \\
6. & Menilai seberapa baik perbaikan bekerja & 2.91 & 0.772 \\
\hline
\end{tabular}

Berdasarkan tabel 3, 4, dan 5 dapat dilihat bahwa dari ketiga dimensi partisipasi keluarga, urutan dari yang tertinggi yaitu dimensi partisipasi dalam pengelolaan diri (2.677 \pm 0.744$)$, kemudian dimensi partisipasi dalam kepercayaan diri (2.601 \pm 0.672$)$ dan dimensi partisipasi keluarga yang terendah yaitu dimensi partisipasi keluarga dalam pemeliharaan diri $(2.035 \pm 0.716)$.

Afitasari, A.I., Krisnawati, B._Gambaran Motivasi dan Partisipasi Keluarga dalam... 
Jurnal Ilmu Keperawatan Medikal Bedah Vol. 3 (2), Bulan November Tahun 2020 , Hal. 32-41 ISSN 2338-2058 (print), ISSN 2621-2986 (online)

Tabel 6

Distribusi Frekuensi Motivasi dan Partisipasi Keluarga

\begin{tabular}{ccc}
\hline Variabel & Frekuensi (f) & Persentase (\%) \\
\hline Motivasi Keluarga & & \\
\hline Rendah & 40 & 26.3 \\
Sedang & 96 & 63.2 \\
Tinggi & 16 & 10.5 \\
\hline Partisipasi Keluarga & & \\
\hline Rendah & 29 & 19.1 \\
Sedang & 98 & 64.5 \\
Tinggi & 25 & 16.4 \\
\hline Total & 152 & 100 \\
\hline
\end{tabular}

Tabel di atas menunjukkan bahwa pada kelompok responden sebagian besar memiliki motivasi keluarga dengan tingkat sedang (63.2\%) sedangkan pada pengukuran partisipasi keluarga sebagian besar ada pada kelom[pok tingkat sedang (64.5\%).

\section{PEMBAHASAN}

\section{Motivasi Keluarga dalam Perawatan Mandiri Pasien Gagal Jantung}

Bentuk motivasi keluarga tertinggi dalam perawatan mandiri pasien adalah kepedulian keluarga mengenai keadaan pasien. Hasil ini juga terjadi pada penelitian Melia (2016) tentang upaya keluarga dalam penyembuhan pasien menggambarkan bahwa kepedulian keluarga dalam kategori cukup baik. Tingkat kepedulian pasangan tidak hanya tentang bagaimana memberikan pengobatan agar pasien cepat sembuh tetapi juga memberikan kasih sayang, perhatian dan semangat untuk menghadapi penyakitnya.

Bentuk motivasi yang kedua adalah penerimaan keluarga mengenai keadaan pasien. Penerimaan keluarga merupakan suatu efek psikologis dan perilaku dari keluarga pasien yang dapat ditunjukkan melalui perhatian, dukungan dan pengasuhan yang dibutuhkan oleh pasien (Wardhani, 2013). Ketiga yaitu pendampingan keluarga saat berkunjung ke pusat layanan kesehatan. Sejalan dengan penelitian di Amerika diketahui bahwa $61 \%$ keluarga sering atau selalu menemani anggota keluarga yang sakit untuk kontrol rutin (Cene, 2015). Pasien yang sering ditemani pada setiap kunjungan memiliki skor pemeliharaan perawatan diri 6.4 poin lebih tinggi dibandingkan dengan mereka yang tidak pernah/jarang didampingi ketika kunjungan (Cene, 2015).

Bentuk motivasi keluarga yang masih perlu ditingkatkan adalah dalam mencari informasi mengenai penyakit yang dialami pasien. Menurut keluarga, informasi yang diberikan dokter saat kontrol sudah cukup, sehingga keluarga tidak mencari informasi lain tentang penyakit yang dialami oleh keluarga. Selama wawancara, mayoritas responden mengatakan bahwa pengobatan medis merupakan pengobatan yang satusatunya ditempuh untuk kesembuhan keluarga dan responden berpendapat bahwa mereka percaya kepada petugas medis sehingga tidak mencari informasi lainnya mengenai penyakit yang dialami pasien. Anggota keluarga merupakan pihak yang mendorong pasien untuk melakukan pengobatan. 
Jurnal Ilmu Keperawatan Medikal Bedah Vol. 3 (2), Bulan November Tahun 2020 , Hal. 32-41 ISSN 2338-2058 (print), ISSN 2621-2986 (online)

\section{Partisipasi Keluarga dalam Perawatan Mandiri Pasien Gagal Jantung}

Hasil penelitian mengenai gambaran partisipasi keluarga dalam perawatan mandiri pasien gagal jantung di RSUD Dr. Moewardi Surakarta didapatkan kesimpulan bahwa tingkat partisipasi yang diberikan keluarga dalam kategori sedang (64.5\%). Sejalan dengan penelitian Ayunarwanti (2019) bahwa didapatkan bahwa 65.7\% responden memiliki perawatan diri yang sedang. Hal ini dikarenakan seseorang yang mengalami sakit jantung akan menjadikan seseorang mengalami penurunan kemampuan dalam melakukan aktivitas sehingga patisipasi keluarga sangatlah diperlukan terutama dalam perawatan diri.

\section{Partisipasi Keluarga dalam Pemeliharaan Diri Pasien}

Partisipasi keluarga dalam pemeliharaan diri pasien menilai partisipasi keluarga dalam kepatuhan pasien mengenai pengobatan dan gaya hidup sehat (mengingatkan dalam olahraga rutin, minum obat, menurunkan konsumsi garam) (Riegel dkk., 2015). Bentuk partisipasi keluarga tertinggi pada dimensi pemeliharaan diri pasien adalah menganjurkan keluarga untuk melakukan kontrol dengan dokter atau perawat. Sejalan dengan penelitian Cene (2015) sebagian besar responden sering mengingatkan untuk melakukan kontrol rutin.

Bentuk partisipasi tertinggi kedua pada self-care management adalah menganjurkan keluarga untuk tidak lupa minum obat. Hasil penelitian ini sesuai dengan penelitian yang dilakukan oleh Conceicao dkk. (2015) yang mendapatkan hasil mean yang tinggi pada ketaatan minum obat. Pasien dengan gagal jantung terutama derajat III dan IV sangat membutuhkan keluarga atau orang lain untuk memenuhi kebutuhan dan melaksanakan self-care (Kaawoan, 2012).

Perilaku yang masih perlu ditingkatkan adalah kepatuhan pasien untuk diet rendah garam, terutama saat makan diluar rumah (Basuray dkk., 2015). Ketidakpatuhan ini dapat disebabkan karena ada hambatan yang dialami pasien dan keluarga. Panduan American Heart Association (AHA) rekomendasi pembatasan garam (natrium) dalam manajemen gagal jantung adalah $1500 \mathrm{mg} /$ hari (Yancy dkk., 2013).

\section{Partisipasi Keluarga dalam Pengelolaan Diri Pasien}

Partisipasi dalam pengelolaan diri tertinggi adalah menyarankan keluarga menghubungi dokter atau perawat untuk panduan yaitu dengan nilai mean 3.39. Panduan penanganan gagal jantung merekomendasikan pembatasan cairan kurang dari 2 liter perhari bagi pasien dengan hiponatremia dan semua pasien dengan retensi cairan yang susah dikontrol dengan penggunaan diuretik (AHA, 2019).

Bentuk partisipasi tertinggi kedua adalah menyarankan keluarga untuk mengonsumsi furosemide tambahan ketika datang keluhan. Hasil kesimpulan yang berbeda dengan penelitian Conceicao dkk. (2015) yang mendapatkan hasil yang rendah pada perilaku komsumsi furosemide ketika ada gejala. Ketidaktahuan keluarga mengenai

Afitasari, A.I., Krisnawati, B._Gambaran Motivasi dan Partisipasi Keluarga dalam... 
Jurnal Ilmu Keperawatan Medikal Bedah Vol. 3 (2), Bulan November Tahun 2020 , Hal. 32-41 ISSN 2338-2058 (print), ISSN 2621-2986 (online)

jenis obat merupakan salah satu faktor rendahnya nilai partisipasi konsumsi furosemide ketika terjadi gejala.

Bentuk partisipasi keluarga dalam pengelolaan diri yang masih perlu untuk ditingkatkan adalah kecepatan dalam mengenali gejala. Keluarga seringkali menyadari ada gejala yang muncul ketika pasien mengatakannya langsung, jika pasien tidak melaporkan gejala yang dialami. Gejala yang dialami pasien antara lain sesak, pembengkakan pada ekstremitas bawah, serta mudah lelah namun, keluarga kurang mengenali dan mengamati suatu gejala kekambuhan gagal jantung (Majid, 2010).

\section{Partisipasi Keluarga dalam Kepercayaan Diri Pasien}

Responden mengatakan bahwa ketika terjadi kekambuhan keluarga membantu pasien untuk mengambilkan obat, menganjurkan beristirahat, serta memijat bagian pundak. Sebagian besar responden menilai apa yang dilakukan dapat meringankan dan mengurangi gejala yang dialami pasien. Sejalan dengan penelitian Wahyuni dan Ovta (2014) mengenai hubungan self-care dan motivasi dengan kualitas hidup bahwa responden yang menilai seberapa baik perbaikan bekerja memiliki angka yang tinggi.

Mengikuti petunjuk pengobatan yang telah diberikan merupakan bentuk kepercayaan dengan nilai tertinggi kedua. Hasil ini sejalan dengan penelitian Cocchieri dkk. (2015) mengenai gambaran self-care pada orang Italia dilihat dari keseluruhan penelitian ini maka yang dimaksudkan kepercayaan adalah mengikuti petunjuk pengobatan adalah kepatuhan dalam meminum obat-obatan, bukan petunjuk pengobatan non farmakologis (Prihatiningsih \& Sudyasih, 2018).

Bentuk partisipasi yang perlu ditingkatkan dalam kepercayaan diri adalah dalam hal mengevaluasi pentingnya gejala. Studi terdahulu merekomendasikan edukasi dengan metode konseling dan dukungan kelompok (cognitive- behavioural interventions) karena mampu meningkatkan efikasi (kepercayaan) diri dalam melakukan self-care (Barnason dkk., 2012). Meskipun demikian, masih diperlukan penelitian lanjutan terhadap strategi di atas untuk menguji keefektifannya pada pasien gagal jantung di Indonesia.

\section{SIMPULAN}

Bentuk motivasi keluarga tertinggi dalam perawatan mandiri pasien adalah kepedulian keluarga mengenai keadaan pasien, penerimaan keluarga mengenai keadaan pasien, dan pendampingan keluarga saat berkunjung ke pusat layanan kesehatan. Bentuk motivasi keluarga yang masih perlu ditingkatkan adalah dalam mencari informasi mengenai penyakit yang dialami pasien.

Bentuk partisipasi keluarga dalam dimensi pemeliharaan diri dengan nilai tertinggi adalah menganjurkan pasien untuk kontrol dengan dokter atau perawat, menganjurkan untuk tidak lupa minum obat. Kemudian untuk bentuk partisipasi yang perlu ditingkatkan adalah meminta makanan rendah garam ketika makan diluar. Bentuk partisipasi keluarga dalam dimensi pengelolaan diri dengan nilai tertinggi adalah menyarankan pasien untuk menghubungi dokter atau perawat untuk panduan, mengonsumsi furosemide tambahan ketika terjadi gejala. Bentuk partisipasi dalam pengelolaan diri terendah adalah kecepatan keluarga dalam mengenali gejala.

Afitasari, A.I., Krisnawati, B._Gambaran Motivasi dan Partisipasi Keluarga dalam... 
Jurnal Ilmu Keperawatan Medikal Bedah Vol. 3 (2), Bulan November Tahun 2020 , Hal. 32-41 ISSN 2338-2058 (print), ISSN 2621-2986 (online)

Bentuk partisipasi keluarga dalam dimensi kepercayaan diri dengan nilai tertinggi adalah mengikuti petunjuk pengobatan, melakukan sesuatu untuk mengurangi gejala. Nilai terendah dalam dimensi kepercayaan diri adalah partisipasi keluarga dalam mengevaluasi pentingnya gejala.

Gambaran tingkat motivasi keluarga dalam perawatan mandiri pasien gagal jantung di RSUD Dr. Moewardi dalam kategori sedang yaitu 63.2\%. Gambaran tingkat partisipasi keluarga dalam perawatan mandiri pasien gagal jantung di RSUD Dr. Moewardi dalam kategori sedang lebih dari separuh (64.5\%). Keluarga diharapkan dapat memberikan motivasi serta berpartisipasi dalam memberikan perawatan untuk meningkatkan kesehatan pasien.

\section{REFERENSI}

Agustina, A., dkk. (2017). Pengalaman pasien gagal jantung kongestif dalam melaksanakan perawatan mandiri. Healthy-Mu Journal, 1(1), 6-14.

American Heart Association. (2019). Heart disease and stroke statistik. Retrieved from http://ahajournal.org.com.

Andersen, K. L., \& Strom, A. (2016). Family caregivers to a patient with chronic heart failure living at home : (Co-Workers) In A Blurred Health Care System. Universitetet $i$ Oslo.

Ayunarwanti, R. (2019). Gambaran self management pada pasien gagal jantung di RSUD Dr. Moewardi Surakarta (Skripsi). Surakarta. Universitas Muhammadiyah Surakarta

Bachrudin, M., \& Najib, M. (2016). In reply: behaviour therapy. The British Journal of Psychiatry. 11(2) 167-182. https://doi.org/10.1192/bjp.111.479.1009-a

Barbara R. (2017). Self-care for the prevention and management of cardiovascular disease and stroke a scientific statement for healthcare professionals from the American Heart Association. Journal American Heart Association: 1-18.

Basuray, A., dkk. (2015). Dietary sodium adher-ence is poor in chronic heart failure patients. Journal of Cardiac Failure, 21(4), 323-329. https://doi.org/10.1016/i.cardfail.2014.12.016.DIETARY

Cene, C. W., (2015). Family member accompaniment to routine medical visits is associated with better self-care in heart failure patients. Chronic Illness Journal, 11(1), 21-32. https://doi.org/10.1177/1742395314532142

Conceicao, A. P., Santos, M. A., Santos, B., \& Cruz, D. (2015). Self-care in heart failure patients. Revista Latino-Americana de Enfermagem, 23(4), 578-586. https://doi.org/10.1590/0104-1169.0288.2591

Erdhayanti, S., Kartinah. (2012). Hubungan tingkat pengetahuan lansia dengan perilaku lansia dalam pemenuhan personal hygiene di Panti Wreda Darma Bakti Pajang Surakarta. Publikasi Ilmiah UMS, 5(1). 16-22.

Fauzi, A. R., \& Yuniarti, S. (2017). The relationship of family support to motivation (intention) for medical treatment in patients with cervical cancer in Ligar Medika Clinic, West Java - Indonesia. International Conference on Applied Science and Health 2017. 12(3), 228-233.

Fikriana, R. (2018). Sistem kardiovaskuler. Yogyakarta: Dee Publisher.

Kaawoan, A. Y,. (2012). Hubungan self care depresi dengan kualitas hidup pasien heart failure di RSUD Prof DR R. D. Kandou Manado. (Tesis). Depok: FK Universitas Indonesia.

Afitasari, A.I., Krisnawati, B._Gambaran Motivasi dan Partisipasi Keluarga dalam... 
Jurnal Ilmu Keperawatan Medikal Bedah Vol. 3 (2), Bulan November Tahun 2020 , Hal. 32-41 ISSN 2338-2058 (print), ISSN 2621-2986 (online)

Kementrian Kesehatan RI. (2018). Situasi kesehatan jantung. Pusat Data dan Informasi Kementrian Kesehatan RI, 1-8.

Kuntjoro, Z. (2002). Dukungan sosial pada lansia. http://www.e-psikologi.co.id

Majid, A. (2010). Asuhan keperawatan pada pasien dengan gangguan sistem kardiovaskular. Yogyakarta: Pustaka Baru Pers

Malisan, E., Wantania, F.E., \& Rotty, L. (2015). Hubungan kadar hematokrit dengan kelas NYHA pada pasien gagal jantung kongestif obesitas sentral yang dirawat jalan dan dirawat inap di RSUP Prof. Dr. R. D. Kandou. Jurnal E-Clinic. 3(2).177-188 https://doi.org/10.35790/ecl.3.2.2015.8604

Melia, Y. (2016). Upaya keluarga dalam penyembuhan pasien penyakit jiwa; studi pada pasien penyakit jiwa di RSJ HB. Sa'anin Padang. Jurnal Ilmu Sosial Mamangan. 5(2).102-112.

Mustikaningtyas, Y., \& Kristinawati, B. (2018). Faktor penyebab rawat inap ulang pasien gagal jantung di RSUD Dr. Moewardi Surakarta. (Skripsi). Surakarta. Universitas Muhammadiyah Surakarta

Perhimpunan Dokter Spesialis Kardiovaskular Indonesia (PERKI). (2015). Pedoman tatalaksana gagal jantung. Edisi Pertama, 14-27.

Prihatiningsih, D., \& Sudyasih, T. (2018). Perawatan diri pada pasien gagal jantung. $\begin{array}{llll}\text { Journal of Cardiovascular Nursing, 26(3), 112-124. } & \text {. }\end{array}$ https://doi.org/10.17509/jpki.v4i2.13443

Riegel, B., Driscoll, A., Suwanno, J. O. M., Moser, D. K., Lennie, T. A., Chung, M. L., \& Wu, J. (2009). Heart failure self-care in developed and developing countries. Journal of Cardiac Failure, 15(6), 508-516. https://doi.org/10.1016/j.cardfail.2009.01.009

Vellone E, dkk. (2013). Validity and reliability of the caregiver contribution to self-care of heart failure index. Journal of Cardiovascular Nursing, 28(3), 245-255. doi: 10.1097/JCN.0b013e318256385e

Wahyuni, A., Ovta, K. (2014). Hubungan Self care dan motivasi dengan kualitas hidup pasien gagal jantung. Jurnal Ilmu Keperawatan, 6(12). 62-72. doi: 10.24198/jkp.v2n2.5

Wardhani, RSP. 2013. Penerimaan keluarga pasien skizofrenia yang menjalani rawat inap. (Skripsi). Surakarta: Universitas Muhammadiyah Surakarta.

Yancy, C. W., dkk. (2013). 2013 ACCF/AHA guideline for the management of heart failure: A report of the american college of cardiology foun-dation/american heart association task force on practice guidelines. Circulation, 128(16). https://doi.org/10.1161/CIR.0b013e31829e8776

Afitasari, A.I., Krisnawati, B._Gambaran Motivasi dan Partisipasi Keluarga dalam... 